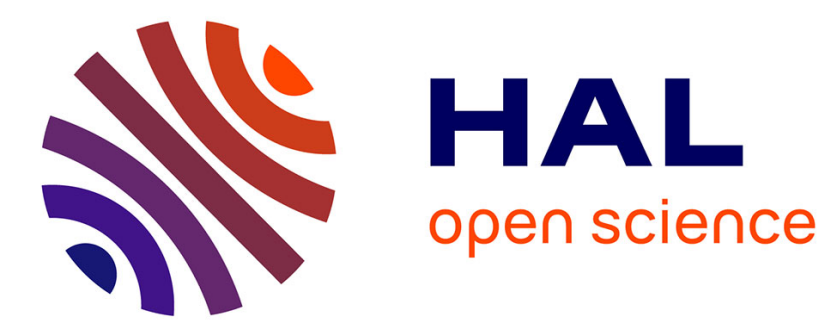

\title{
Critical consequences of finding three pathogenic mutations in an individual with recessive disease
}

Sally Halsall, Gemma Thornton, Adeline Nicholas, Howard Martin, Christopher Woods

\section{- To cite this version:}

Sally Halsall, Gemma Thornton, Adeline Nicholas, Howard Martin, Christopher Woods. Critical consequences of finding three pathogenic mutations in an individual with recessive disease. Journal of Medical Genetics, 2010, 47 (11), pp.769. 10.1136/jmg.2010.079277 . hal-00557401

\section{HAL Id: hal-00557401 \\ https://hal.science/hal-00557401}

Submitted on 19 Jan 2011

HAL is a multi-disciplinary open access archive for the deposit and dissemination of scientific research documents, whether they are published or not. The documents may come from teaching and research institutions in France or abroad, or from public or private research centers.
L'archive ouverte pluridisciplinaire HAL, est destinée au dépôt et à la diffusion de documents scientifiques de niveau recherche, publiés ou non, émanant des établissements d'enseignement et de recherche français ou étrangers, des laboratoires publics ou privés. 


\section{Communication to Journal of Medical Genetics:}

Critical consequences of finding three pathogenic mutations in an individual with recessive disease

Sally Halsall ${ }^{1}$,

Adeline K. Nicholas ${ }^{2}$,

Gemma Thornton ${ }^{2}$,

Howard Martin ${ }^{1}$,

C Geoffrey Woods ${ }^{2}$

1. Genetics laboratories, East Anglian Medical Genetics Service, Cambridge University Hospitals NHS Foundation Trust, Hills Road, Cambridge. CB2 OQQ

2. Cambridge Institute for Medical Research, Wellcome Trust/MRC Building, Addenbrooke's Hospital, Hills Road, Cambridge. CB2 0XY

We report the unexpected finding of three different nonsense mutations in two unrelated individuals with a classical autosomal recessive disease; that is one in which two pathogenic mutations in trans are expected. This finding of 'triple pathogenic mutations' appears to be a rare phenomena ${ }^{1}$, for which we can find no guiding literature for incidence, mechanism or consequence; however they have been reported previously in the recessive disorders Insensitivity to Pain with Anhidrosis due to TRKA mutations (OMIM 256800) and Gaucher disease due to GDI mutations (OMIM 230800). For mutation analysis in research or clinical settings such findings can have significant implications, whilst for genetic counselling the consequences can be profound.

The two individuals we report both had a clinical diagnosis of autosomal recessive primary microcephaly (MCPH), a disorder characterised by congenital microcephaly and mental retardation ${ }^{2,3}$. MCPH is genetically heterogeneous and can be caused by mutations in at least five genes ${ }^{4}$. Fortunately for clinical practice $2 / 5$ ths of cases are explained by mutations in the gene $A S P M^{5}$. To date all definitive mutations found in $A S P M$ have been nonsense and predicted to lead to nonsense mediated decay of the 
$A S P M$ message - the exception being a large intragenic deletion in a Sicilian family ${ }^{3,5-8}$.

During 2009 thirty-six possible MCPH cases were referred to us and analysed in an NHS Molecular Genetics laboratory. We found ASPM mutations in six; a detection rate of $16 \%$. However, in two cases we found three different nonsense mutations. In the first: c.3796G>T (p.Glu1266X), c.7569_7570delAA (p.Gln2523fs) and c.10060C>T (p.Arg3354X), and in the second: c.3977G>A (p.Trp1326X), c.4184G>A (p.Trp1395X) and c.6994C > T (pArg2332X). We subsequently assessed the parents and found that in each case one parent carried two of the nonsense mutations. For case 1 a parent carried in cis c.3796G $>\mathrm{T}$ in exon 16 and c.10060C>T in exon 26. And for case 2 it was c.3977G > A in exon 17 and c.6994C>T in exon 18. From this we concluded that ASPM haplotypes exist bearing two separate nonsense mutations in cis.

Having found these two instances of triple pathogenic ASPM mutations, we were surprised this had not been reported previously. Our own research strategy for ASPM mutation detection was guided by reporting of few recurrent mutations, and no mutation hot spots. Based on this, every exon of ASPM would be sequenced and the data analysed sequentially, starting from the first exon and proceeding until two mutations were found. This means that any potential third nonsense mutation may have evaded detection if it lay in an unanalysed exon. On retrospective review, we had sequenced ASPM in 84 research index cases with a clinical diagnosis of MCPH. In 31 cases all exons were sequenced and no mutations found. In 53 cases two mutations in $A S P M$ were identified, and in 12 of these not all exons had been analysed. However, upon analysis of the remaining exons no additional mutations were found.

To calculate the incidence of triple mutations in $A S P M$ in $\mathrm{MCPH}$, we amalgamated our service and research data. There were a total of 59 confirmed cases of MCPH with ASPM mutations, 17 in non-consanguineous families, 42 in consanguineous (10 of which were recurrent mutations on the same haplotype). Therefore there were 66 $(17 * 2+32 * 1) A S P M$ mutation bearing haplotypes, of which two carried double nonsense mutations, so giving an incidence of $3 \%$. 
We considered how two separate pathological mutations might occur on the same allele. Upon examination, all four double nonsense mutations would clearly be regarded as pathogenic and were entirely typical of other reported ASPM mutations in MCPH. Positional analysis of all mutations showed that they were spread throughout the gene and whilst four were $\mathrm{C}>\mathrm{T}$ transitions, $A S P M$ has a cytosine/guanidine content typical of coding genes $(4,037 / 10,887=37 \%)$ suggesting excess cytosine methylation misrepair was unlikely to be contributory. In addition, like most $A S P M$ mutations, all four were novel, previously unreported mutations. This is of importance as we had considered that the size of the $A S P M$ gene, exceeding $10.8 \mathrm{~Kb}$ of coding sequence, may have contributed to the occurrence of double mutations. A haplotype of a large gene should be more likely to accrue a second mutation than that of a small gene. Additionally, older mutations might be expected to be more widespread in populations and hence should be more likely to be multiply inherited. However, such second mutations would be expected to arise on older haplotypes, and as all of the disease mutations are novel, we have no evidence supporting this. The presence of an untranslated ASPM pseudogene would allow two further possible mechanisms for the presence of multiple mutations. As pseudogenes are not subject to evolutionary pressure they can accumulate multiple mutations. Sequencing primers which are not specific for the translated gene may return sequence from a pseudogene which contains identical or similar primer binding sites. This has been well described for the NF1 gene where the presence of at least 3 pseudogenes considerably complicates the molecular diagnosis ${ }^{9}$. Alternatively recombination with the pseudogene may introduce multiple mutations from the pseudogene into the ASPM gene. The molecular diagnosis of Gaucher disease and Congenital Adrenal Hyperplasia is affected by the presence of pseudogenes for the GBA gene and CYP21 respectively ${ }^{10,11}$. However, we have no evidence to support the presence of an ASPM pseudogene.

For genetic counselling the identification (or overlooking) of 'triple pathogenic mutations' has important consequences. Where all three mutations are found in an index case, individuals carrying a haplotype with two of the three pathogenic mutations could be wrongly assigned as 'affected'. This could apply to a parent, but 
more likely a sibling. Prenatal diagnosis requires the identification of all three mutations.

However, a much more dangerous situation could occur where incomplete sequencing means only two of three mutations are found in the index case. Consequently, if one parent has both "discovered" mutations, then the affected child may be falsely designated as having uniparental heterodisomy. Alternatively, if one parent is unavailable for testing, and the remaining parent carries neither of the detected mutations, non-paternity may be invoked and an erroneous low recurrence risk given. More importantly, unaffected siblings may be wrongly ascribed as 'affected' if they have both detected mutations, or falsely ascribed a 'non-carrier' if they have neither detected mutation but do carry the undetected mutation. This would be a particular problem in prenatal diagnosis.

It is unclear how common triple pathogenic mutations are, but even if they only comprise $1 \%$ of cases it is essential that they are not overlooked. We suggest that research teams should ensure that a report that states 'all exons sequenced' also means 'all exons analysed'. Moreover, clinical teams should not only continue to confirm research findings in a proband but should always check that segregation is correct, meaning that each parent carries one pathogenic mutation. This simple approach will ensure that the finding of 'triple pathogenic mutations' in a recessive disease does not cause clinical problems of misdiagnosis.

\section{References}

1. Mardy S, Miura Y, Endo F, Matsuda I, Sztriha L, Frossard P, Moosa A, Ismail EA, Macaya A, Andria G, Toscano E, Gibson W, Graham GE, Indo Y. Congenital insensitivity to pain with anhidrosis: novel mutations in the TRKA (NTRK1) gene encoding a high-affinity receptor for nerve growth factor. Am J Hum Genet. 1999 Jun;64(6):1570-9.

2. Woods CG, Bond J, Enard W. Autosomal recessive primary microcephaly (MCPH): a review of clinical, molecular, and evolutionary findings. Am J Hum Genet. 2005 May;76(5):717-28.

3. Passemard S, Titomanlio L, Elmaleh M, Afenjar A, Alessandri JL, Andria G, de Villemeur TB, Boespflug-Tanguy O, Burglen L, Del Giudice E, Guimiot F, Hyon C, Isidor B, Mégarbané A, Moog U, Odent S, Hernandez K, Pouvreau N, Scala I, Schaer M, Gressens P, Gerard B, Verloes A. Expanding the clinical 
and neuroradiologic phenotype of primary microcephaly due to ASPM mutations. Neurology. 2009 Sep 22;73(12):962-9.

4. Thornton GK, Woods CG. Primary microcephaly: do all roads lead to Rome? Trends Genet. 2009 Nov;25(11):501-10.

5. Nicholas AK, Swanson EA, Cox JJ, Karbani G, Malik S, Springell K, Hampshire D, Ahmed M, Bond J, Di Benedetto D, Fichera M, Romano C, Dobyns WB, Woods CG. The molecular landscape of ASPM mutations in primary microcephaly. J Med Genet. 2009 Apr;46(4):249-53.

6. Gul A, Tariq M, Khan MN, Hassan MJ, Ali G, Ahmad W. Novel proteintruncating mutations in the ASPM gene in families with autosomal recessive primary microcephaly. J Neurogenet. 2007 Jul-Sep;21(3):153-63.

7. Desir J, Cassart M, David P, Van Bogaert P, Abramowicz M. Primary microcephaly with ASPM mutation shows simplified cortical gyration with antero-posterior gradient pre- and post-natally. Am J Med Genet A. 2008 Jun $1 ; 146 \mathrm{~A}(11): 1439-43$.

8. Kumar A, Blanton SH, Babu M, Markandaya M, Girimaji SC. Genetic analysis of primary microcephaly in Indian families: novel ASPM mutations. Clin Genet. 2004 Oct;66(4):341-8.

9. Gasparini P, Grifa A, Origone P, Coviello D, Antonacci R, Rocchi M. Detection of a neurofibromatosis type I (NF1) homologous sequence by PCR: implications for the diagnosis and screening of genetic diseases. Mol Cell Probes. 1993 Oct; 7(5):415-8.

10. Horowitz, M.; Wilder, S.; Horowitz, Z.; Reiner, O.; Gelbart, T.; Beutler, E. : The human glucocerebrosidase gene and pseudogene: structure and evolution. Genomics 1989 4:87-96.

11. Tusié-Luna MT, White PC. Gene conversions and unequal crossovers between CYP21(steroid 21-hydroxylase gene) and CYP21P involve different mechanisms. Proc Natl Acad Sci U S A. 1995 Nov 7;92(23):10796-800

Competing Interest: None declared.

Licence for Publication statement

The Corresponding Author has the right to grant on behalf of all authors and does grant on behalf of all authors, an exclusive licence (or non exclusive for government employees) on a worldwide basis to the BMJ Publishing Group Ltd to permit this article (if accepted) to be published in JMG and any other BMJPGL products and sublicences such use and exploit all subsidiary rights, as set out in our licence (http://group.bmj.com/products/journals/instructions-for-authors/licence-forms)." 